\title{
IMPROVING THE CAPABILITY OF CONTAINER AND CHICKEN SLAUGHTERHOUSE BUSINESS IN MANAGING SUSTAINABLE WASTE RETENTION TIME
}

\author{
Maya Dewi Dyah Maharani, Soecahyadi, and Mohammad Adam \\ Universitas Sahid, Indonesia. \\ mayasudarsono@gmail.com
}

\begin{abstract}
The Indonesian chicken industry is a key sector for the national economy, supplying $65 \%$ of all animal protein and employing $10 \%$ of the national labor. With the increasing business competition, it is necessary to increase the capability in managing the waste retention time generated. This study focuses on increasing the capability of the chicken slaughterhouse to manage the retention time of waste. The method used is the Multi-Dimensional Scaling (MDS) analysis to calculate The Capability of Container and Chicken Slaughtered Business in Managing Waste Retention Time. This prospective analysis is carried out to analyse the degree of strength and dependency relationships by giving a score of the level of direct or indirect influence between elements of leverage that have been generated from MDS analysis. Prospective analysis results in the form of key factors that form the basis of change scenario that can be achieved. The results can be concluded that the determinants factor of the Improving the Capability of Container and Slaughtered Chicken Business in managing sustainable waste retention time are: (i) Methods and ways of utilizing technology Wastewater Treatment Plant, (ii) Local Government Arrangements, (iii) Waste quantity and quality, and (iv) Financial Management.
\end{abstract}

Keywords: Chicken-slaughterhouse, Waste; Retention-Time, MDS, Prospective

\section{INTRODUCTION}

The Indonesian poultry industry is a key sector for the national economy, supplying $65 \%$ of all animal protein and employing $10 \%$ of the national labor force (Ferlito, Carmelo. 2018). The demand for broiler chickens brings up competition among the increasing business people. The consumer satisfaction of broiler carcasses in chickenslaughterhouse is positively and significantly influenced by the physical quality assurance factor and the seller's skills, response to the consumer and the completeness of the appliance (Irvan Galantini, Budi Hartono, and Eko Nugroho 2015). Slaughterhouse wastes from chicken processing include water and organic solid by-products. Chicken carcass yields are typically about 70 - 75 percent of the live weight, the rest is accepted as inedible waste (Omer F. Sari, Saim Ozdemir, Ahmet Celebt. 2016). With the increasing business competition, it is necessary to increase the capability in managing the waste retention time generated. It is necessary as an alternative material in the preparation of the regulation of the chicken slaughterhouse business permit in Indonesia

\section{METHODS}

The study was carried out from October year 2018 to April 2019 year, and conducted in Chicken-Slaughterhouse of Bogor, Semarang. Data analysis methods used are: (i). Multi Dimensional Scaling (MDS); (ii) Leverage analysis; (iii). Monte Carlo Analysis; and (iv) Prospective analysis method

\section{Multi-Dimensional Scaling}

To assess the sustainability status of on Container and Slaughtered Chicken Bussiness in managing sustainable waste retention time used the Rap-Retention-ChickenSlaughterhouse (RRCS) method has been modified from the Rapfish program with Multi-Dimensional Scaling techniques. In the MDS attributes to be measured and could be mapped within the distance of Euclidian with the following formula:

$d_{1,2}=\sqrt{\left(X_{1}-X_{2}\right)^{2}+\left(Y_{1}-Y_{2}\right)^{2}+\left(Z_{1}-Z_{2}\right)^{2}+\ldots}$

Information :

$\mathrm{d}_{1,2} \quad=$ Euclidean distance

$\mathrm{X}, \mathrm{Y}, \mathrm{Z}=$ Attributes

$1,2=$ Observation 
The euclidian distance between these two points $\left(\mathrm{d}_{1,2}\right)$ then in MDS is projected into two-dimensional euclidean distance $\left(\dot{\mathrm{D}}_{1,2}\right)$ based on the regression formula in the following equation:

$\mathrm{D}_{1,2}=\mathrm{a}+\mathrm{bD}_{1,2}+\mathrm{c}$

Information :

a $\quad=$ intercept

$\mathrm{b} \quad=$ slope

c $\quad=$ error

MDS analysis, the objects are mapped in one point that is close together. The MDS technique used is ALSCAL algorithm which is easily available in almost every statistical software (SPSS and SAS). RRCS in principle makes iterating the regression process in such a way, in order to gets the smallest e value and reachs the equation $(a=0)$. Iteration stops if stress is $<0.25$. For attributes as much as $\mathrm{m}$, stress value formulated in the following equation:

stress $=\sqrt{\frac{1}{m} \sum_{k=1}^{m}\left(\frac{\sum_{i} \sum_{j}\left(D_{i j k}^{2}-d_{i j k}^{2}\right)^{2}}{\sum_{i} \sum_{j} d_{i j k}^{2}}\right)}$....

The stress value is shown in Table 1

\begin{tabular}{lll}
\hline No & Stress Value & Conformity \\
\hline 1 & $>20.00 \%$ & Bad \\
2 & $>(10.00-20.00) \%$ & Enough \\
3 & $>(5.00-10.00) \%$ & Good \\
4 & $(2.50-5.00) \%$ & Very good \\
\hline
\end{tabular}

\section{Leverage Analysis}

Leverage analysis to determine the effect of stability if one of the attributes is omitted when ordinated. Leverage analysis results show the percent in the root mean square of each attribute. Attributes that have the highest percentage are the most sensitive attributes to sustainability

\section{Monte Carlo Analysis}

To evaluate the effect of error on ordination value, Monte Carlo analysis is used, to evaluate the effects of random errors in the estimation process, and to evaluate the actual value.

\section{Prospective analysis}

Prospective analysis produces classification of factors related to a problem and is mapped into 4 (four) quadrants, namely: (1) Input; (2) stake; (30) output; and (4) unused. Quadrant Input is the determinant quadrant. This quadrant contains attributes that have a strong influence and low dependencies inter-attribute. Quadrant-II contains attributes that have strong influence and strong interdependence between attributes. Quadrant-III is contains attributes that have low influence and strong inter-attribute dependencies. Quadrant-IV is contains attributes that have low influence and low interdependence between attributes (Desi Puspaningrat Luh Putu, S. Pribadi. Eko, Dyah Maharani Maya Dewi. 2018, Muh. Ridwan dan Hartrisari Hardjomidjojo. )

\section{RESULTS AND DISCUSSION}

The RRCS analysis shows that the sustainability status value is $39.07 \%$ that is categorized as a less sustainable value. The results were validated with a $38.64 \%$ Monte Carlo value indicating a very small difference of distinction of 0.43 or less than $1 \%$. These values indicate that the effect of an error, or the impact of a relatively small scoring error. While the stress value of $14.46 \%$ and coefficient of determination (R2) has a high enough value of 0.9496 which means that the included attributes/components have a considerable role in explaining the diversity of the Improving the capability of Container and Slaughtered Chicken Bussiness in managing sustainable waste retention time. Based on the MDS analysis and leverage analysis showed that the attributes/factors/components that has the highest Root Mean Square (RMS) value is Waste quantity and quality (0.32), it indicates that the attributes/factors/components of the ecology dimension could be Improving the capability of Container and Slaughtered Chicken Bussiness in managing sustainable waste retention time. 
This attributes/factors/components is a key factor that needs to be leveraged (Table 1)

Table 1. Dimensions and attributes of leverage produced by MDS

\begin{tabular}{lc}
\hline Attributes & Root Mean Square \\
\hline 1. Financial Management & 0.08 \\
2. The exchange rate of Container and Slaughtered & 0.13 \\
Chicken Bussiness & 0.12 \\
3. Competition between Container and Slaughtered & \\
$\quad$ Chicken Bussiness Ordinary and Biomass & 0.03 \\
4. The sustainability motivation of the businessman & \\
$\quad$ Container and Slaughtered Chicken & 0.32 \\
5. Waste quantity and quality & 0.21 \\
6. Channel Dimensions Wastewater Treatment Plant & 0.05 \\
7. Government supervision & 0.05 \\
8. Local Government Arrangements and directives & 0.05 \\
9. Conflicts with local communities & 0.06 \\
10. Methods and ways of utilizing technology & \\
$\quad$ Wastewater Treatment Plant & \\
\hline
\end{tabular}

The ten attributes of leverage are then carried out by assessment of influence levels between attributes, either directly or indirectly. It is done considering there is a relationship between each attribute in the The relationship between these attributes can be an influence or dependency between attributes. Results of prospective analysis obtained as in Picture 1.

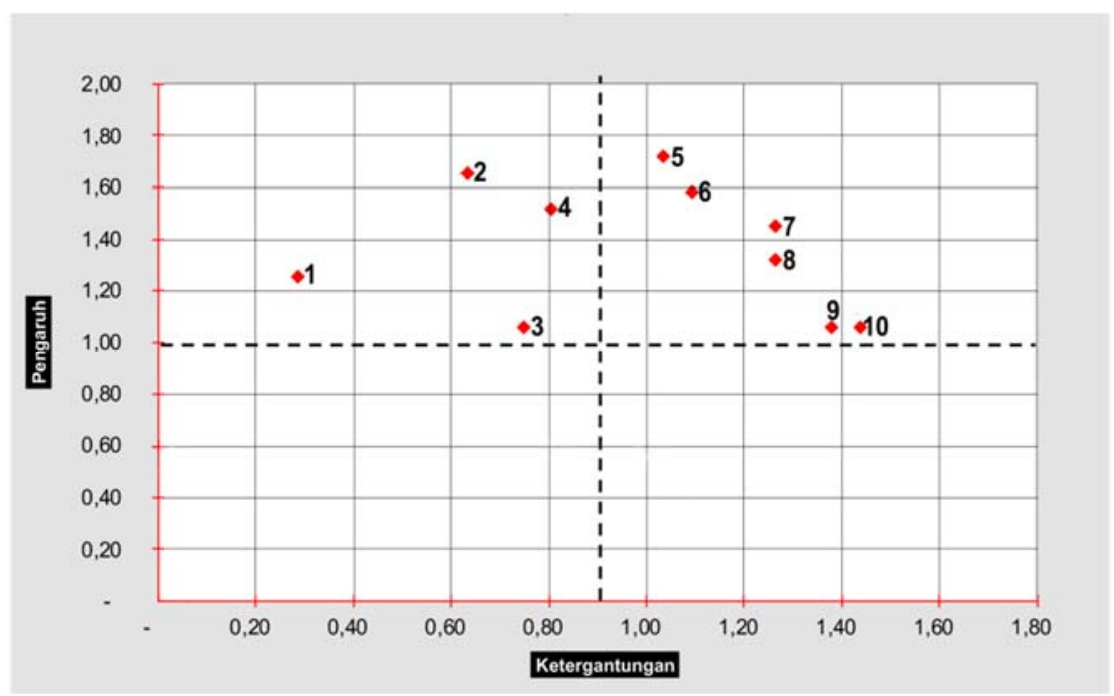

Picture 1: Level of importance of driving factors on container and slaughtered chicken bussiness in managing sustainable waste retention time

Description of Picture 1:

$1 \quad$ : Waste quantity and quality

2 : Methods and ways of utilizing technology Wastewater Treatment Plant

3 : Financial Management

$4 \quad$ : Local Government Arrangements and directives

$5 \quad$ : The exchange rate of Container and Slaughtered Chicken Bussiness

$6 \quad$ : Conflicts with local communities

$7 \quad$ : Government supervision

8 : The sustainability motivation of the businessman Container and Slaughtered Chicken

9 : Channel Dimensions Wastewater Treatment Plant

10 : Competition between Container and Slaughtered Chicken Bussiness Ordinary and Biomass

From Picture 1 It appears that the 4 attributes/components (Methods and ways of utilizing technology Wastewater Treatment Plant; Local Government Arrangements and directives; Waste quantity and quality and Financial Management) have high influence and low dependence. Success can be achieved if the 4 attributes/components 
are followed up through harmonization of action plans by business people and local governments. The quantity and quality of potentially sellable solid waste depends on the efficiency of the processing methods and the health of the prior to processing. Blood, feathers, head, feet and inedible viscera and in some cases treated solids make up the chicken slaughterhouse solids in the poultry industry. The treatment of solid waste should aim to produce value-added sellable by-products, such as pet, animal or aquaculture feed components, energy through biogas production and agricultural fertilizer. The long retention time of the plant, accomplished by a low dilution of the substrate, is a vital component of the process stability when treating high protein substrates like slaughterhouse waste (A.E.W. Ek, S. Hallin, L. Vallin, A. Schnurer, M. Karlsson, 2011).

While the other 6 attributes (The exchange rate of Container and Slaughtered Chicken Bussiness; Conflicts with local communities; Government supervision; The sustainability motivation of the businessman Container and Slaughtered Chicken; Channel Dimensions Wastewater Treatment Plant; and Competition between Container and Slaughtered Chicken Bussiness Ordinary and Biomass) have high influence and high dependence (Maya Dewi Dyah Maharani, Dem Vi Sara, 2018).

\section{CONCLUSION AND SUGGESTIONS}

Based on the analysis results can be concluded that the determinants factor of the Improving the Capability of Container and Slaughtered Chicken Business in managing sustainable waste retention time are: (i) Methods and ways of utilizing technology Wastewater Treatment Plant, (ii) Local Government Arrangements and directives, (iii) Waste and quality, and (iv) Financial Management. We advise the local government to place officers in accordance with the capability management of technological of waste retention time.

\section{ACKNOWLEDGEMENT}

Authors wishing to acknowledge assistance or encouragement from colleagues, special work by technical staff Chicken Slaughterhouse at Bogor and Semarang. Author also thank to Sahid University through the Research and Community Service Institute (LPPM), which has funded this activity through the Internal Community Service Fund (Contract Number :118.17/USJ-11/H.54/2019)

\section{REFERENCES}

Schnurer, A. and Karlsson, M. (2011). Slaughterhouse Waste Co-Digestion Experiences from 15 years of Full-Scale Operation. https://www.researchgate.net/publication/267689298. DOI: 10.3384/ecp1105764

Putu, D.P. L., Pribadi. S., Eko, dan Maharani, M.D.D. (2018). Faktor-faktor Penentu Status Berkelanjutan Tempat Penampungan Dan Potong Ayam Di Pondok Rumput Kota Bogor, Program Pasca Sarjana S-2 Institut Pertanian Bogor

Ferlito, C. and H. Respatiadi (2018). Policy Reforms on Poultry Industry in Indonesia. ECONSTOROR. Econstor.eu/handle/10419/190822

Galantini, I., Hartono, B. dan Nugroho, E. (2015). Analisis kualitas pelayanan terhadap kepuasan konsumen pembeli karkas broiler di Rumah Potong Ayam (RPA), Kelurahan Kampung Mandar, Kabupaten Banyuwangi. Jurnal Ilmu-ilmu Peternakan, 25(1):47-54

Dahliani, L. dan Maharani, M.D.D. (2018). Palm Oil Sustainable Management Using MDS Model from Social Dimension. Proceeding $20183^{\text {rd }}$ International Conference on Education, Sport, Arts and Management Engineering

Maharani, M.D.D. dan Sara, D.V. (2018). Model Sruktural Pengelolaan Tempat Penampungan dan Potong Ayam Secara Berkelanjutan Dalam Mendukung Ketahanan Pangan. Buku Seminar Peran Matematika, Sains, dan Teknologi dalam Mencapai Tujuan Pembangunan Berkelanjutan. Universitas Terbuka

Ridwan, M. dan Hardjomidjojo, H. (2016). Aplication Prospective Analysis to Formulate Development Scenario Dangke as Competitive Local Product in District Enrekang South of Sulawesi. Sekolah. Pascasarjana Teknologi Industri Pertanian. IPB. Bogor.

Sari, O.F, Ozdemir, S. and Celebi, A. (2016). Utilization and Management of Poultry Slaughterhouses Wadte with new Methods. EURASIA 2016 WASTE MANAGEMENT SYMPOSIUM 